\title{
ZEOLITIZATION OF SEWAGE SLUDGE ASH WITH A FUSION METHOD
}

\author{
Jolanta Latosińska ${ }^{1}$ \\ 1 Faculty of Environmental, Geomatic and Energy Engineering, Kielce University of Technology, 25-314 Kielce, \\ Al. Tysiąclecia Państwa Polskiego 7, Poland, e-mail: jlatosin@tu.kielce.pl
}

Received: 2016.08.16

Accepted: 2016.09.26 Published: 2016.11.01

\begin{abstract}
The study shows the results of zeolitization of municipal sewage sludge ash with the indirect fusion method followed by a hydrothermal method. The zeolitization of sewage sludge ash was conducted at the melting temperature of $550^{\circ} \mathrm{C}$ and the melting time of 60 minutes, crystallization temperatures of $60^{\circ} \mathrm{C}$ and $90^{\circ} \mathrm{C}$, crystallization time of 6 hours and the SSA: $\mathrm{NaOH}$ ratio of $1: 1.8 ; 1: 1.4$. The research of modified sewage sludge ashes included the observation of changes of ash particles surface and the identification of crystalized phases. The zeolitization of sewage sludge ash at the ratio of SSA:NaOH 1.0:1.4 did not cause the formation of zeolite phases. On the other hand, the zeolitization at the ratio of SSA:NaOH 1.0:1.8 resulted in the formation of desired zeolite phases such as zeolite Y (faujasite) and hydroxysodalite. The presented method of sewage sludge ash zeolitization allows to obtain highly usable material. Synthesized zeolites may be used as adsorbents and ion exchangers. They can be potentially used to remove heavy metals as well as ammonia from water and wastewater.
\end{abstract}

Keywords: sewage sludge ash, zeolitization, fusion method, faujasite, hydroxysodalite.

\section{INTRODUCTION}

Municipal sewage sludge ash is an increasingly popular waste generated all over the world. It is estimated that approximately 1.2 million tons of sewage sludge ashes are produced in North America and the European Union annually (Donatello et al., 2010; Latosińska and Gawdzik, 2014). The realization of prevailing European Union norms (86/278/EEC, 91/271/EEC, 99/31EC) and the growth of the amount of the incinerated sewage sludge contributes to the increase of the quantity of sewage sludge ash.

Sewage sludge ash can be used as an additive to the production of building materials e.g bricks (Liew et al., 2004), cement mortar (Monzo et al., 2003) and aggregates (Wainwright and Cresswell, 2001). However, the dominant method of sewage sludge ash utilization is depositing in landfills.

Zeolites are microporous hydrated aluminosilicates, which are categorized into natural and synthetic groups. Their crystal structure contains numerous pores and cavities of different sizes giv- ing them a unique ion-exchange, sorption and catalytic properties (Wdowin et al. 2014). Because of these properties, zeolites have found applications in many areas such as environmental engineering (Mulgundmath et al. 2012), construction industry (de Gennaro et al. 2004), agriculture (Polat et al. 2004) and refinery industries (Zhu et al. 2013). Zeolites are used for the removal of radionuclides from liquid radioactive waste (Osmanoglu 2006), as well as for the removal of nitrates and heavy metals from water and wastewater (Franus and Wdowin 2010; Lee et al. 2000; Qiu and Zheng, 2009). Zeolites are also capable of the removal of volatile petroleum derivatives from flue gas (Bandura et al. 2016), the fixation of phosphates, the neutralization of acid wastes and the clean-up of sewerage (Polat et al. 2004).

Synthetic zeolites can be produced from natural resources such as bentonite (Ruiz et al. 1997), perlite (Pichór et al. 2014) and kaolinite (Littlewood et al. 2015). Moreover, obtaining synthetic zeolites with the use of waste materials is a well-known method. The use of fly ashes 
from coal is a common method of obtaining different kinds of synthetic zeolites (Querol et al. 2002; Kazemain et al. 2010; Juan 2007; Fotovat et al. 2009; Carlos et al. 2009). There are also known examples of obtaining zeolites from rice husk ash (Thuadaij et al. 2012), waste porcelain (Wjima and Ikegami 2009), and paper sludge ash (Wajima and Munakata 2014).

The constituents of coal fly ash are mainly silica, alumina, glassy and crystalline aluminosilicates, as well as a large variety of micro and trade components (Boycheva et al. 2015; Żygadło et al. 2011). The aluminosilicate glass is a readily available source of $\mathrm{Si}$ and $\mathrm{Al}$ for zeolite synthesis (Lee et al. 2000). The content of silicon and aluminium determines the usefulness of fly ashes for the synthesis of zeolites, while the $\mathrm{SiO}_{2} / \mathrm{Al}_{2} \mathrm{O}_{3}$ ratio conditions the formation of a particular type of zeolites (Dyer 1988).

Different methods of the synthesis of zeolites from ashes are also known, i.e. a direct hydrothermal method (Querol et al. 1995; Wałek et al. 2008 ,), an indirect fusion followed by a hydrothermal method (Shigemoto et al. 1993; Rayalu et al. 2000; Zhang et al. 2011), a two-step hydrothermal method (Tanaka et al. 2002) and a molten salt liquid free method (Park et al. 2000).

Molina \& Pole (2004) evaluated the direct hydrothermal method and the indirect fusion method at different reaction conditions of time, temperature and proportion of $\mathrm{NaOH}$ to coal fly ash. According to these results, the fusion method gives better results in terms of shorter time necessary to obtain a product with a high crystallinity.

The composition of sewage sludge ashes is similar to the composition of coal fly ashes (tab.1). It predisposes the use of sewage sludge as a raw material for the synthesis of zeolites. Sewage sludge ashes contain a significant concentration of aluminosilicate. The concentration of aluminosilicate in sewage sludge ashes is caused among others by the components of washing powders present in wastewater (Petterson et al. 2008).

The literature provides only a few examples of zeolites formed by the synthesis from sewage sludge ashes. Lee et al. (2007) studied the synthesis of zeolite from the incineration of sewage sludge fly ash by the hydrothermal method. The small amount of zeolite $\mathrm{P}$ was synthesized in $1 \mathrm{~N}$ of $\mathrm{NaOH}$ solution and a relatively large amount of hydroxysodalite was synthesized in $3 \mathrm{~N}$ and 5 $\mathrm{N}$ of $\mathrm{NaOH}$ solution with a similar peak intensity.
While recovering phosphorous salt from sewage sludge ash, Takahashi et al. (2001) studied the zeolitization of an aluminium phosphate. In this case, the aluminium phosphate is reacted with calcium sulfate, thereby forming a calcium phosphate. Then phosphorus free aluminium reacted with sodium silicate to a form of zeolite.

The aim of this study was the feasibility of the synthesis of zeolites from municipal sewage sludge ash. It was a pioneering study on the zeolitization of sewage sludge ash by the fusion method. The study covered the tests on the influence of the activation temperature, the crystallization temperature and the ratio of SSA: $\mathrm{NaOH}$ on the synthesis of zeolites.

\section{MATERIAL AND METHODS}

\section{Materials}

Sewage sludge from a mechanical biological municipal wastewater treatment plant in Sikówka near Kielce was used in this study. The wastewater treatment plant receives sewage from Kielce agglomeration, located in the central part of Poland. Sewage sludge from this wastewater treatment plant was obtained after the anaerobic stabilization, drainage and drying in a disc dryer. Sewage sludge ash was obtained as a result of sewage sludge incineration. Sewage sludge was dried in a laboratory drier at $105^{\circ} \mathrm{C}$. Then, it was crushed in a mortar to a fraction $<125 \mu \mathrm{m}$. Sewage sludge was incinerated in a laboratory furnace

Table 1. Chemical composition of ashes

\begin{tabular}{|c|c|c|c|}
\hline \multirow{2}{*}{ Component } & \multicolumn{2}{|c|}{ Sewage sludge ash, \% } & Fly ash, \% \\
\cline { 2 - 4 } & $\begin{array}{c}\text { Latosińska } \\
\text { and Gawdzik } \\
2014\end{array}$ & $\begin{array}{c}\text { Chen et al. } \\
\text { 2006; Wang } \\
\text { et al. 2005 }\end{array}$ & $\begin{array}{c}\text { Lee et al. } \\
2010\end{array}$ \\
\hline $\mathrm{SiO}_{2}$ & 35.72 & 43.6 & 38.49 \\
\hline $\mathrm{Al}_{2} \mathrm{O}_{3}$ & 6.70 & 16.6 & 15.87 \\
\hline $\mathrm{Fe}_{2} \mathrm{O}_{3}$ & 9.56 & 10.4 & 9.59 \\
\hline $\mathrm{CaO}$ & 17.46 & 5.61 & 14.17 \\
\hline $\mathrm{MgO}$ & 4.51 & 1.40 & 1.84 \\
\hline $\mathrm{SO}_{3}$ & 1.21 & 0.24 & n.d. \\
\hline $\mathrm{K}_{2} \mathrm{O}$ & 1.61 & 2.34 & 1.6 \\
\hline $\mathrm{Na}_{2} \mathrm{O}$ & 0.52 & 0.82 & 0.93 \\
\hline $\mathrm{P}_{2} \mathrm{O}_{5}$ & 19.0 & n.d. & n.d. \\
\hline $\mathrm{TiO}_{2}$ & 1.00 & n.d. & n.d. \\
\hline $\mathrm{Mn}_{2} \mathrm{O}_{3}$ & 0.14 & n.d. & n.d. \\
\hline
\end{tabular}

n.d. - no data 
Naberthem at the temperature of $600^{\circ} \mathrm{C}$ within 11 minutes. After the combustion, the sample remained in the furnace until it cooled down to the temperature of $20^{\circ} \mathrm{C}$.

\section{Characterisation methods}

The chemical compositions of sewage sludge and sewage sludge ash were determined by using the X-ray fluorescence spectroscopy (XRF) method.

Phase analysis of sewage sludge ash and sewage sludge ash after the zeolitization was performed with X-ray diffraction (XRD) using Bruker-AXS D8 DAVINCI diffractometer. The identification of phases was performed by the comparison of recorded diffractograms and the benchmarks found in a base ICDD PDF-2 and PDF-4+ 2014.

The size and shape of crystals in the synthesized material were observed by the scanning electron microscopy (SEM), model QUANTA FEG 250.

\section{Zeolite synthesis by fusion method}

In this study, test zeolites were synthesized by two-stage methods: fusion and hydrothermal treatment. Sewage sludge ash particles in the amount of $10 \mathrm{~g}$ were mixed and ground with granular $\mathrm{NaOH}$ to obtain a homogeneous mixture. The mixture was heated in an electric laboratory furnace at the temperature of $550{ }^{\circ} \mathrm{C}$ for 1 hour in air atmosphere. Different ratios of sewage sludge ash to $\mathrm{NaOH}$ samples were used to explore the effect of this parameter on the zeolitization (table 2). The sintered mixture was ground and mixed with distilled water (the applied concentration $3 \mathrm{~N} \mathrm{NaOH}$ ), followed by an aging process with an agitation in a shaking water bath at a giv-

Table 2. Experimental conditions of sewage sludge ash zeolitization

\begin{tabular}{|c|c|c|c|}
\hline \multirow{2}{*}{ Sample } & $\begin{array}{c}\text { SSA:NaOH } \\
\text { g/g }\end{array}$ & $\begin{array}{c}\text { Activation tem- } \\
\text { perature, }{ }^{\circ} \mathrm{C}\end{array}$ & $\begin{array}{c}\text { Crystallization } \\
\text { temperature, }{ }^{\circ} \mathrm{C}\end{array}$ \\
\cline { 3 - 4 } & time $12 \mathrm{~h}$ & time $6 \mathrm{~h}$ \\
\hline S1 & $1: 1.4$ & 60 & 60 \\
\hline S2 & $1: 1.4$ & 60 & 90 \\
\hline S3 & $1: 1.4$ & 90 & 60 \\
\hline S4 & $1: 1.4$ & 90 & 90 \\
\hline S5 & $1: 1.8$ & 60 & 60 \\
\hline S6 & $1: 1.8$ & 60 & 90 \\
\hline S7 & $1: 1.8$ & 90 & 60 \\
\hline S8 & $1: 1.8$ & 90 & 90 \\
\hline
\end{tabular}

en temperature. Then the mixture was crystallized under static conditions at the given temperature. After the completion of crystallization, the solid product was washed several times with distilled water until the $\mathrm{pH}$ of solution reached 10.0, then dried at $105^{\circ} \mathrm{C}$ for 10 hours. The synthesis conditions for each sample are shown in Table 2.

\section{RESULTS AND DISCUSSION}

The characteristics of sewage sludge and sewage sludge ash are presented in Table 3 . Sewage sludge ash contained $\mathrm{SiO}_{2}$ and $\mathrm{Al}_{2} \mathrm{O}_{3}$ in the ratio of 3.94 .

Figure 1 shows SEM of sewage sludge ash. Sewage sludge ash has no porous and rough structure.

The XDR diffractograms were presented in figure 2 and figure 3. The patterns of S1, S2, S3, S4 and S5 samples indicated that no zeolite structures were formed. XRD patterns of samples S1-S5 indicated that samples contained apatite,

Table 3. Characteristics of sewage sludge and sewage sludge ash

\begin{tabular}{|c|c|c|c|}
\hline Parameter & Unit & Sewage sludge & $\begin{array}{c}\text { Sewage sludge } \\
\text { ash }\end{array}$ \\
\hline $\mathrm{pH}$ & - & 7.5 & - \\
\hline moisture & $\%$ & 72.6 & - \\
\hline $\mathrm{SiO}_{2}$ & $\%$ & 8.81 & 20.8 \\
\hline $\mathrm{Al}_{2} \mathrm{O}_{3}$ & $\%$ & 2.11 & 5.28 \\
\hline $\mathrm{Fe}_{2} \mathrm{O}_{3}$ & $\%$ & 3.74 & 9.45 \\
\hline $\mathrm{CaO}$ & $\%$ & 5.66 & 14.3 \\
\hline $\mathrm{MgO}$ & $\%$ & 1.42 & 3.72 \\
\hline $\mathrm{SO}_{3}$ & $\%$ & 0.01 & 1.45 \\
\hline $\mathrm{K}_{2} \mathrm{O}$ & $\%$ & 0.58 & 1.51 \\
\hline $\mathrm{Na}_{2} \mathrm{O}$ & $\%$ & 0.16 & 0.407 \\
\hline $\mathrm{P}_{2} \mathrm{O}_{5}$ & $\%$ & 7.06 & 19.4 \\
\hline $\mathrm{TiO}_{2}$ & $\%$ & 0.32 & 0.725 \\
\hline $\mathrm{Mn}_{2} \mathrm{O}_{3}$ & $\%$ & 0.03 & 0.104 \\
\hline $\mathrm{SrO}$ & $\%$ & 0.02 & 1.45 \\
\hline ZnO & $\%$ & 0.03 & 0.355 \\
\hline $\mathrm{BaO}$ & $\%$ & 0.04 & 0.091 \\
\hline $\mathrm{CuO}$ & $\%$ & 0.02 & 0.048 \\
\hline TOC & $\%$ mas. & 33.69 & - \\
\hline \multicolumn{4}{|c|}{ Phases analysis: } \\
\hline $\begin{array}{l}\text { Amorphous } \\
\text { substance }\end{array}$ & $\%$ mas. & - & 76.71 \\
\hline Quartz & $\%$ mas. & - & 9.12 \\
\hline Calcite & $\%$ mas. & - & 4.06 \\
\hline Dolomite & $\%$ mas. & - & 3.28 \\
\hline Muscovite & $\%$ mas. & - & 4.42 \\
\hline Other & $\%$ mas. & - & 2.41 \\
\hline
\end{tabular}




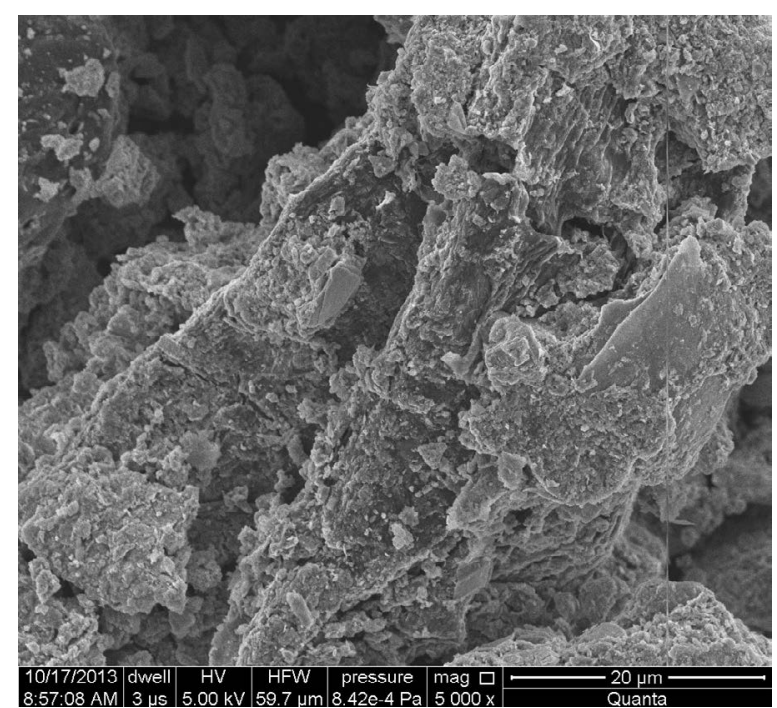

Figure 1. SEM of sewage sludge ash.

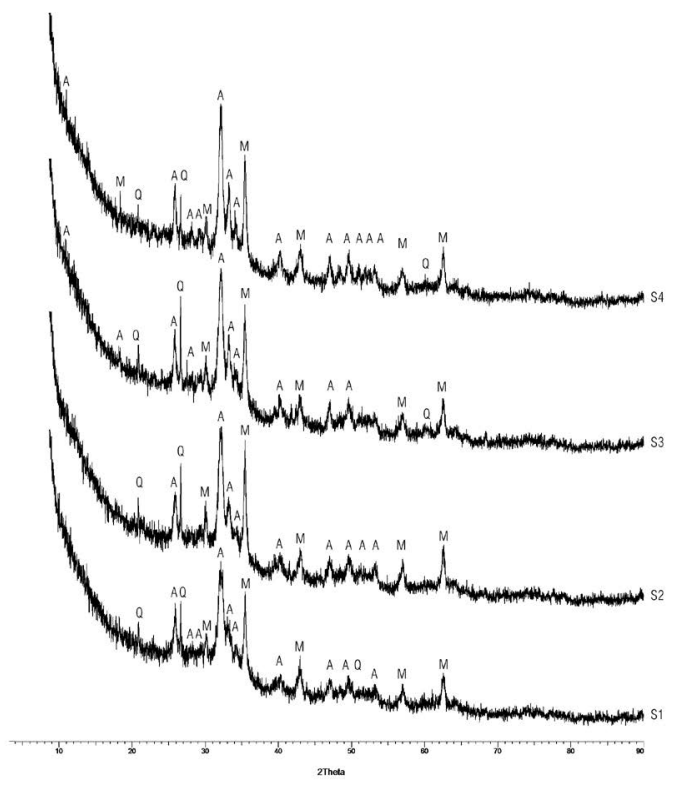

Figure 2. XRD patterns of the synthetic zeolites; SSA: $\mathrm{NaOH}$ - 1.0:1.4; A - apatite, $\mathrm{M}$ - magnetite, Q - Quartz.

quartz and magnetite. Therefore, different activation temperatures and crystallization temperatures did not cause any differences in developing crystalline phases for samples of ratio SSA:NaOH 1:1.4. On the other hand, as far as the S5 sample is concerned, the lack of zeolite forms was potentially caused by an insufficient value of activation temperature and crystallization temperature $-60^{\circ} \mathrm{C}$.

For samples S6, S7, S8 synthesized for ratio SSA:NaOH 1:1.8, the diffractograms present the zeolite structures (fig. 3). S6 sample is characterized by the presence of the faujasite (zeolite Y).

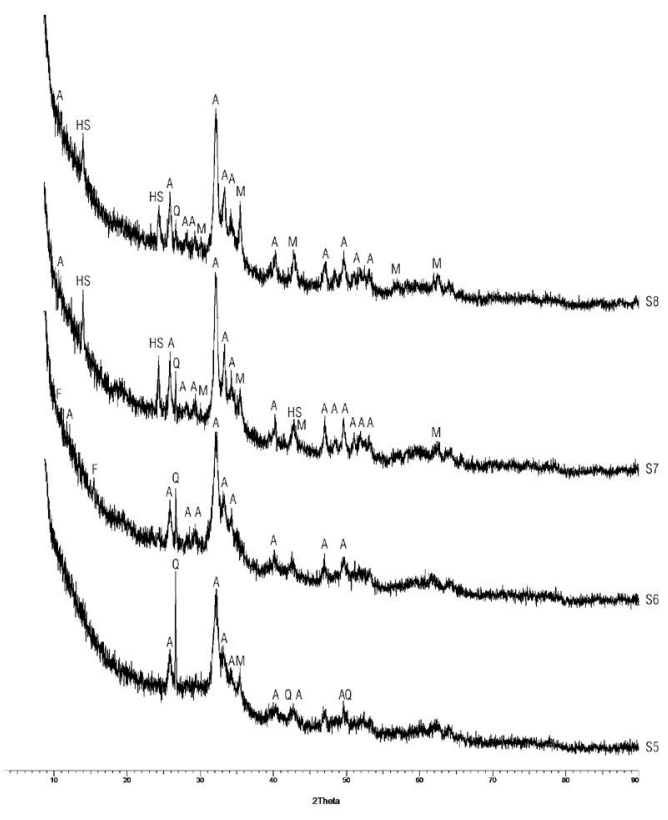

Figure 3. XRD patterns of the synthetic zeolites; SSA:NaOH - 1.0:1.8; A - apatite, $\mathrm{M}$ - magnetite, Q - Quartz, F - faujasite, HS - hydroxysodalite.

Depending on the silica to alumina ratio of the framework raw material, synthetic faujasite zeolites are divided into $\mathrm{X}$ and $\mathrm{Y}$ zeolites. In $\mathrm{X}$ zeolites, the ratio is between 2 and 3, while in $\mathrm{Y}$ zeolites it is 3 or higher (Stamires 1973; Htun et al. 2012). According to Shigemoto et al. (1993) the synthesis of faujasite requires a high $\mathrm{Si} / \mathrm{Al}$ value. If the raw material is rich in aluminum oxide, it give Na-A zeolite instead of faujasite. The sewage sludge ash which was used in the study is a high-silica ash. The obtained faujasite for the zeolitization conditions of S6 sample confirms that - similarly as was the case of coal fly ash zeolitization - the zeolitization in the temperature of $90^{\circ} \mathrm{C}$ is the most favorable (Fukui et al.2006). On the XRD pattern there are no intensive peaks, while in S6 sample, apart from faujasite there is apatite and quartz.

The diffractograms of samples S7 and S8 show that as a result of sewage sludge ash zeolitization, the hydroxysodalite was formed both in $60^{\circ} \mathrm{C}$ and $90{ }^{\circ} \mathrm{C}$ crystallization temperatures. Hydroxysodalite has the same framework structure as sodalite. Sodalite is one of the microporous crystalline zeolites which consists of the cubic array of $\beta$-cages (Bayati et al. 2009). XRD patterns of S7 and S8 indicated that at high temperatures, above $90^{\circ} \mathrm{C}$, and high sodium hydroxide, $3 \mathrm{~N}$ and above, as well as at prolonged reaction time zeolites tend to form sodalite structure (Murayama et al. 2002). 
The morphology of samples S1, S2 and S4, obtained at the lowest SSA: $\mathrm{NaOH}$ ratio have porous surface (Figures 4, 5, 7). Whereas S3 (Fig. 6 ) is characterized by a consistent structure with spherical forms indicating that crystalline forms are beginning to develop. The S4 structure is not homogeneous. Apart from the structure which is evidently porous, there are also surfaces with spheroidal forms as in the S3 sample.

The S5 sample structure (Fig. 8) is also not homogeneous. Apart from the porous structure, there are also forms with the shape similar to long needles with uneven surface. The S6 sample structure of zeolite faujasite is an octahedron shape (Fig. 9). The S7 and S8 samples present hydroxysodalite with particle size smaller than $5 \mu \mathrm{m}$ (Fig. 10, Fig. 11).

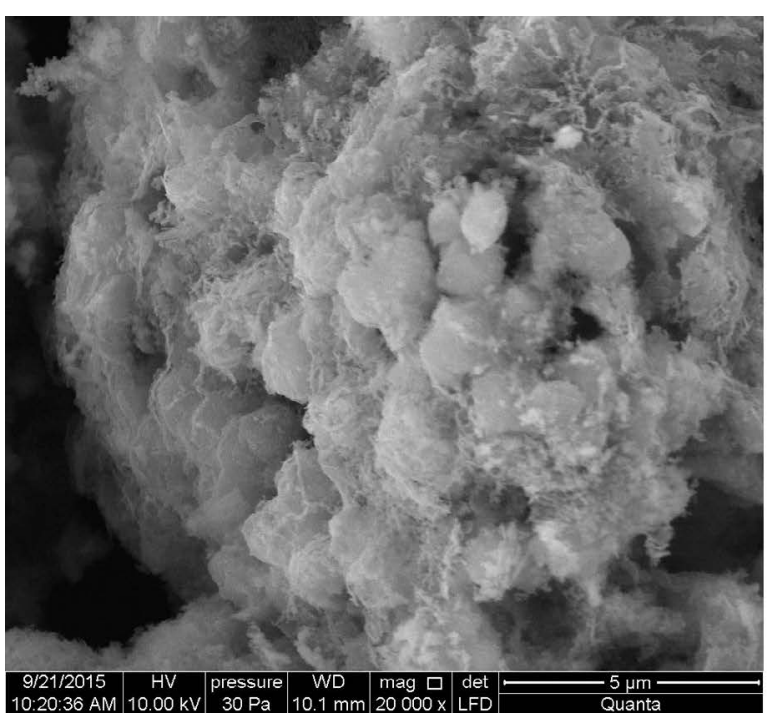

\section{CONCLUSION}

As a result of sewage sludge ash zeolitization with a fusion method the faujasite and hydroxysodalite were obtained. The results indicate that zeolitization of sewage sludge ash effects the structure of the product and sewage sludge ash can be used as a raw material for synthetic zeolites.

On the basis of the tests results of sewage sludge zeolitization, the literature based regularity for coal fly ash was confirmed. The zeolitization of ash for the ratio SSA: NaOH 1.0:1.8 is more advantageous in comparison to zeolitization for SSA: $\mathrm{NaOH}$ with the value of 1.0:1.4 while keeping other parameters of the process the same. The obtained zeolites can by potentially used for the removal of heavy metals from wastewater.

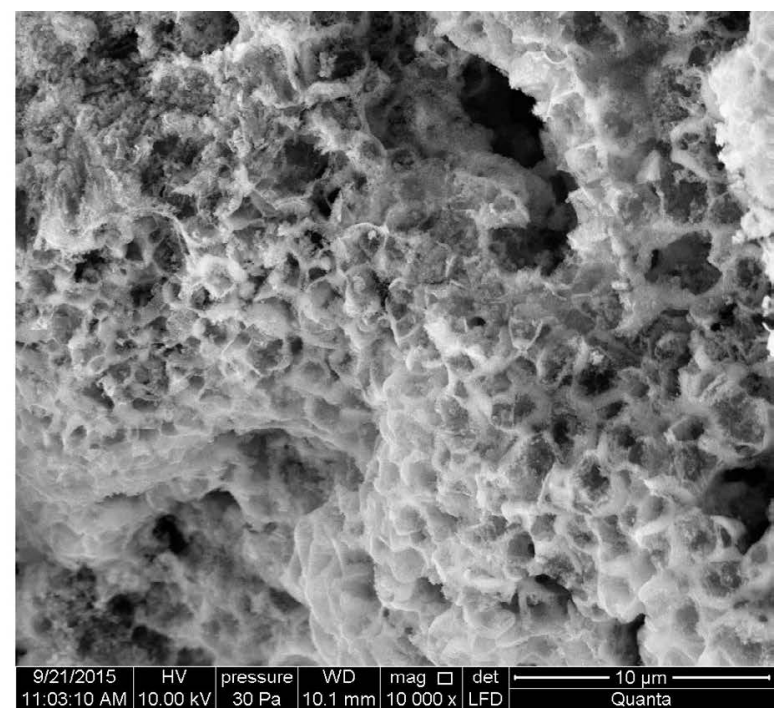

Figure 4. SEM of sample S1
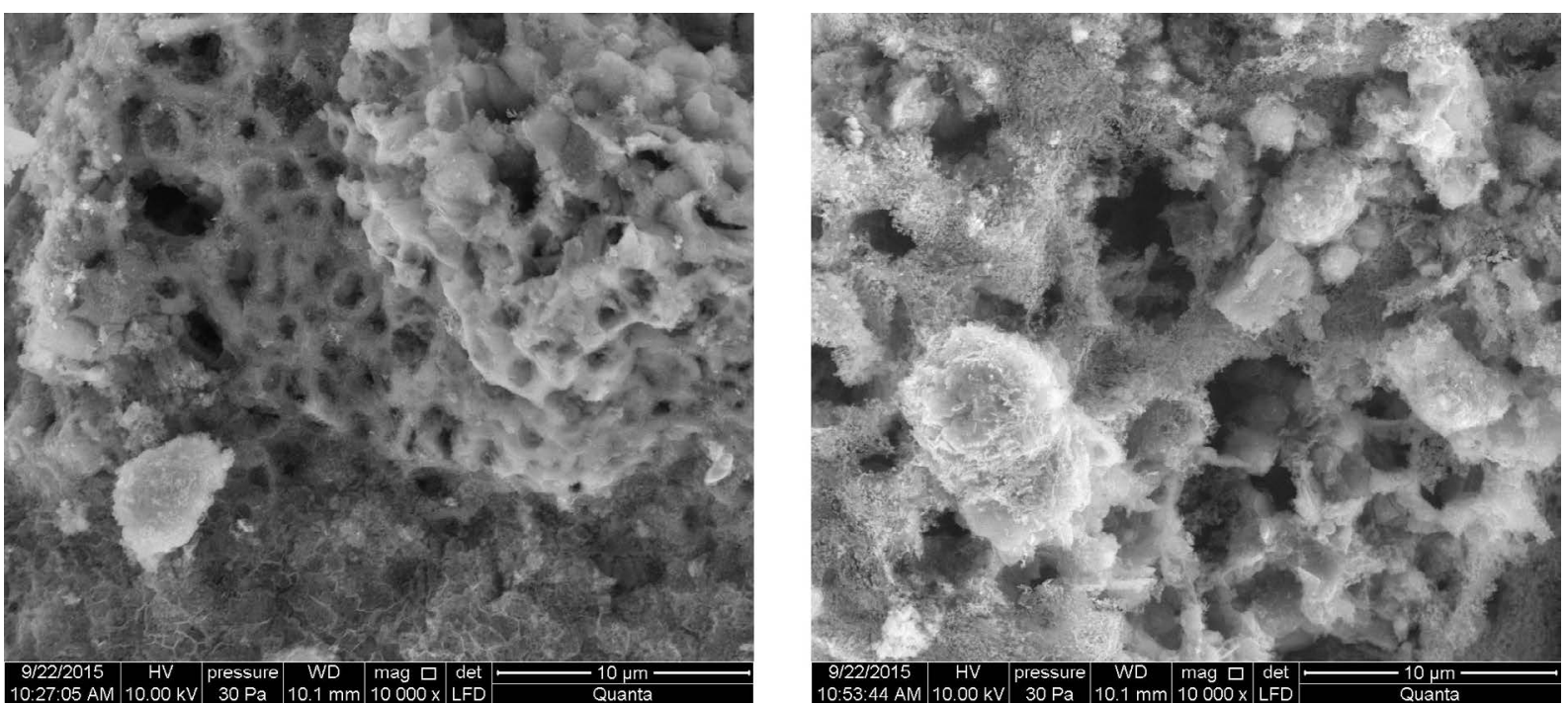

Figure 5. SEM of sample S2 

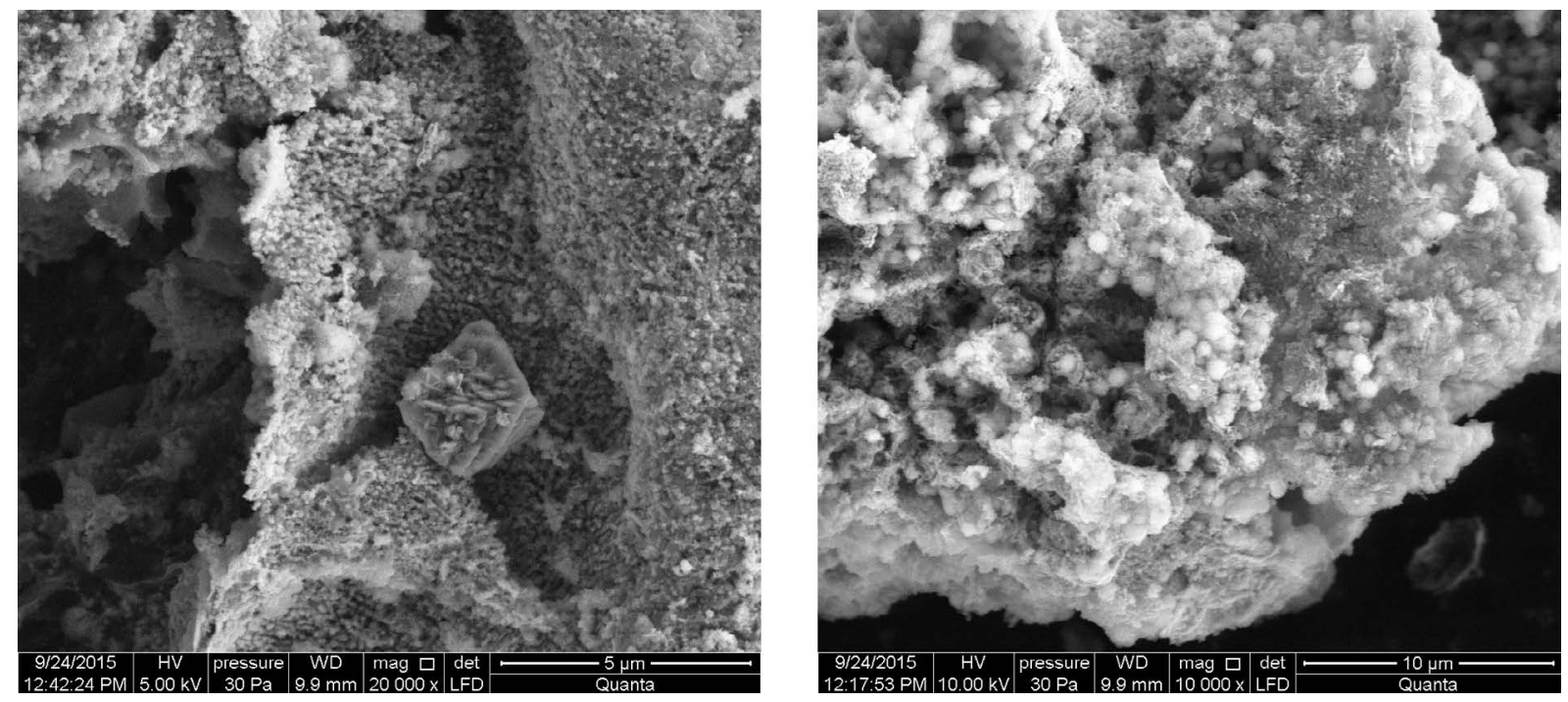

Figure 6. SEM of sample S3
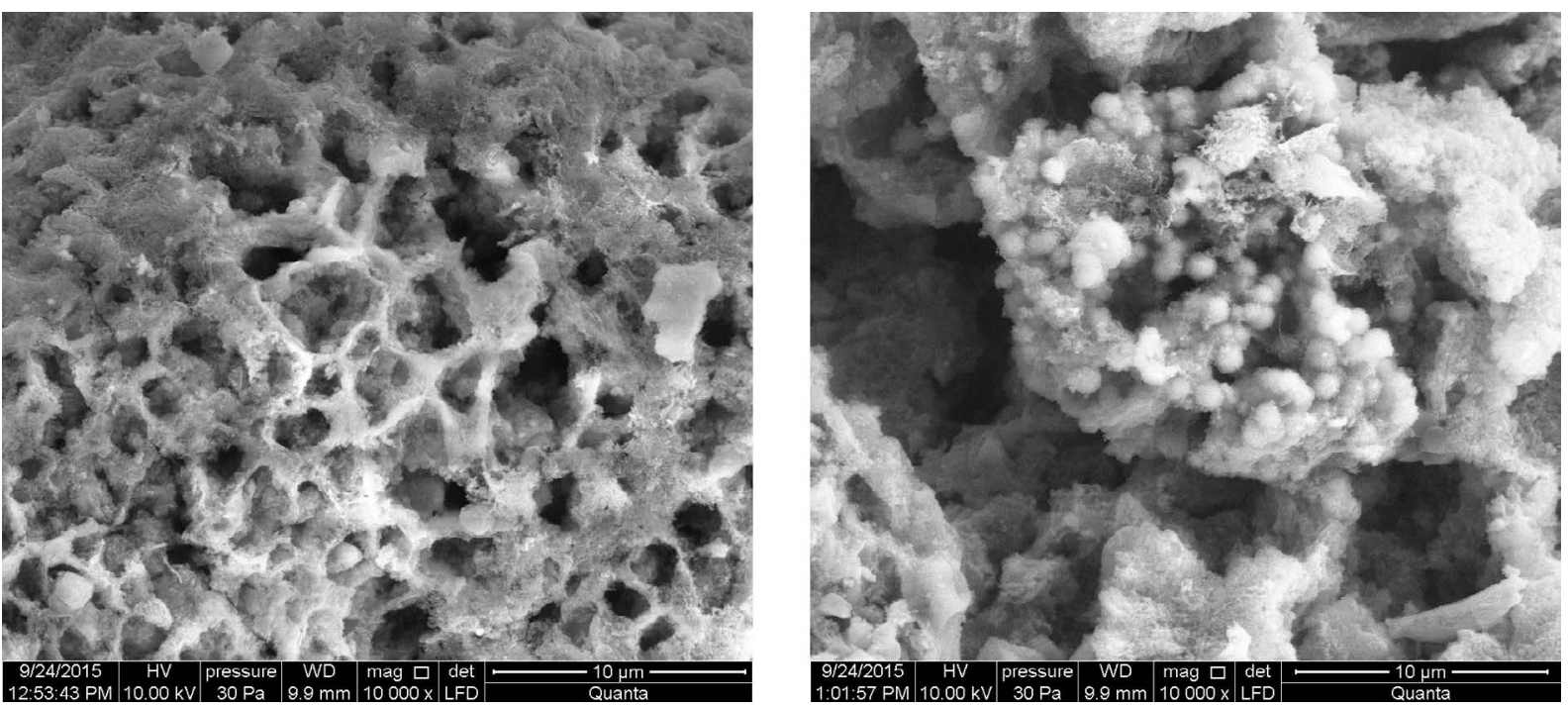

Figure 7. SEM of sample S4
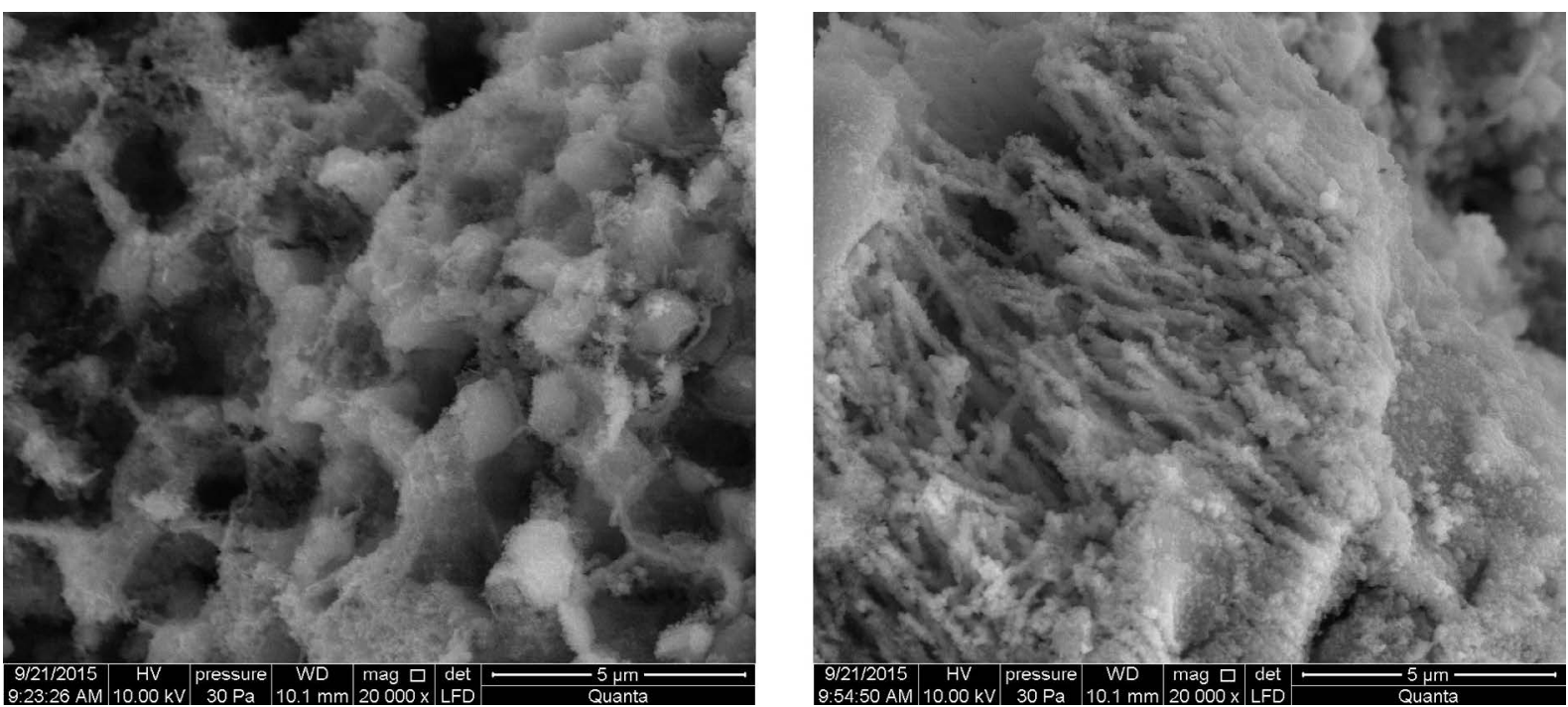

Figure 8. SEM of sample S5 

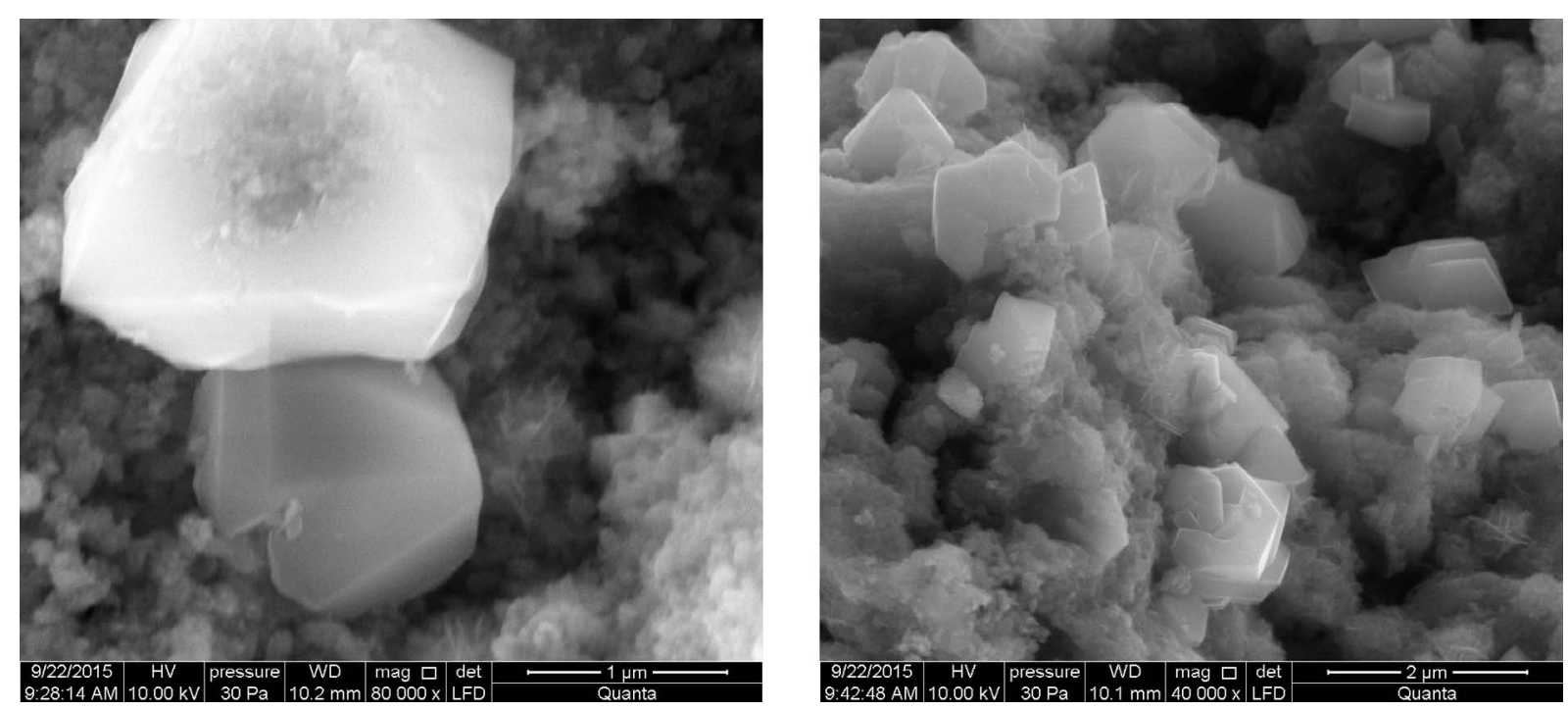

Figure 9. SEM of sample S6
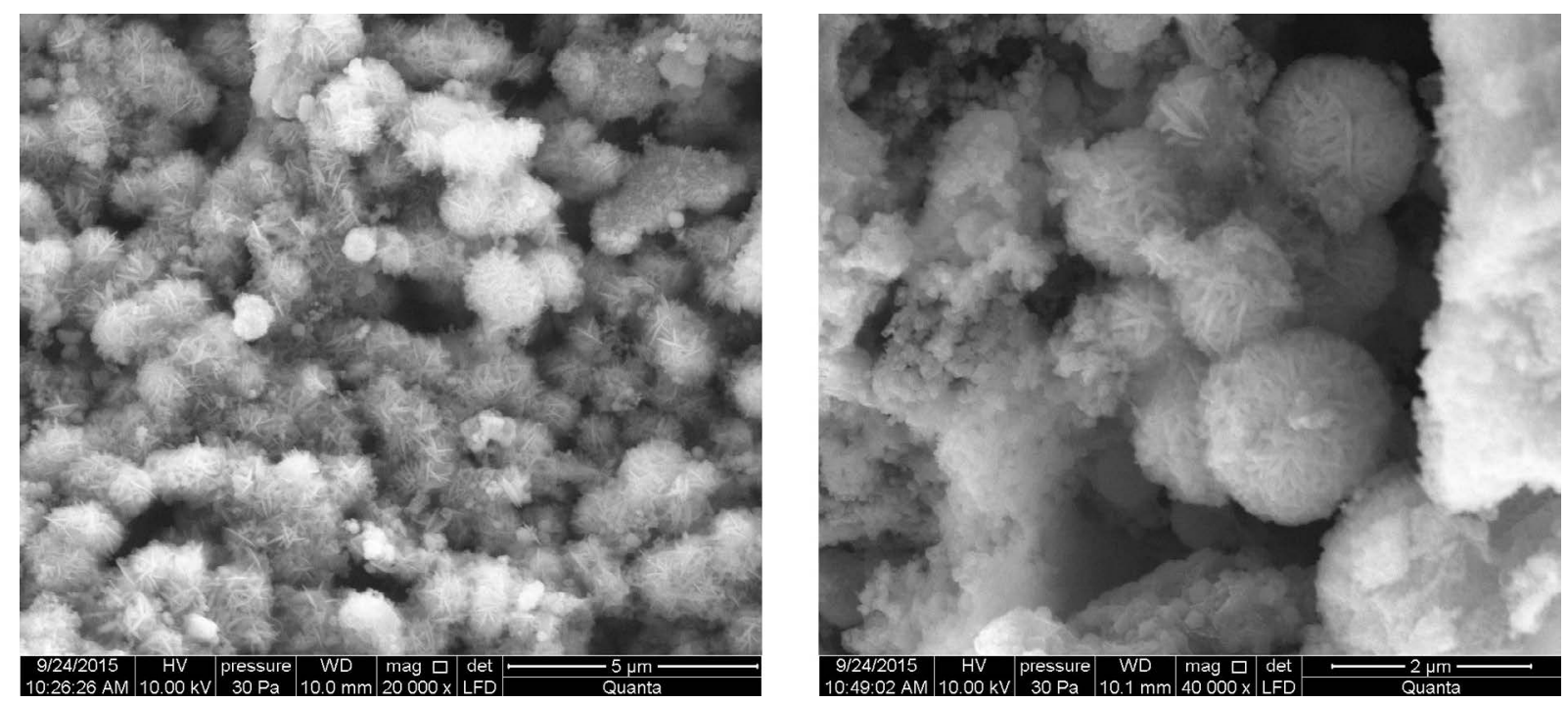

Figure 10. SEM of sample S7
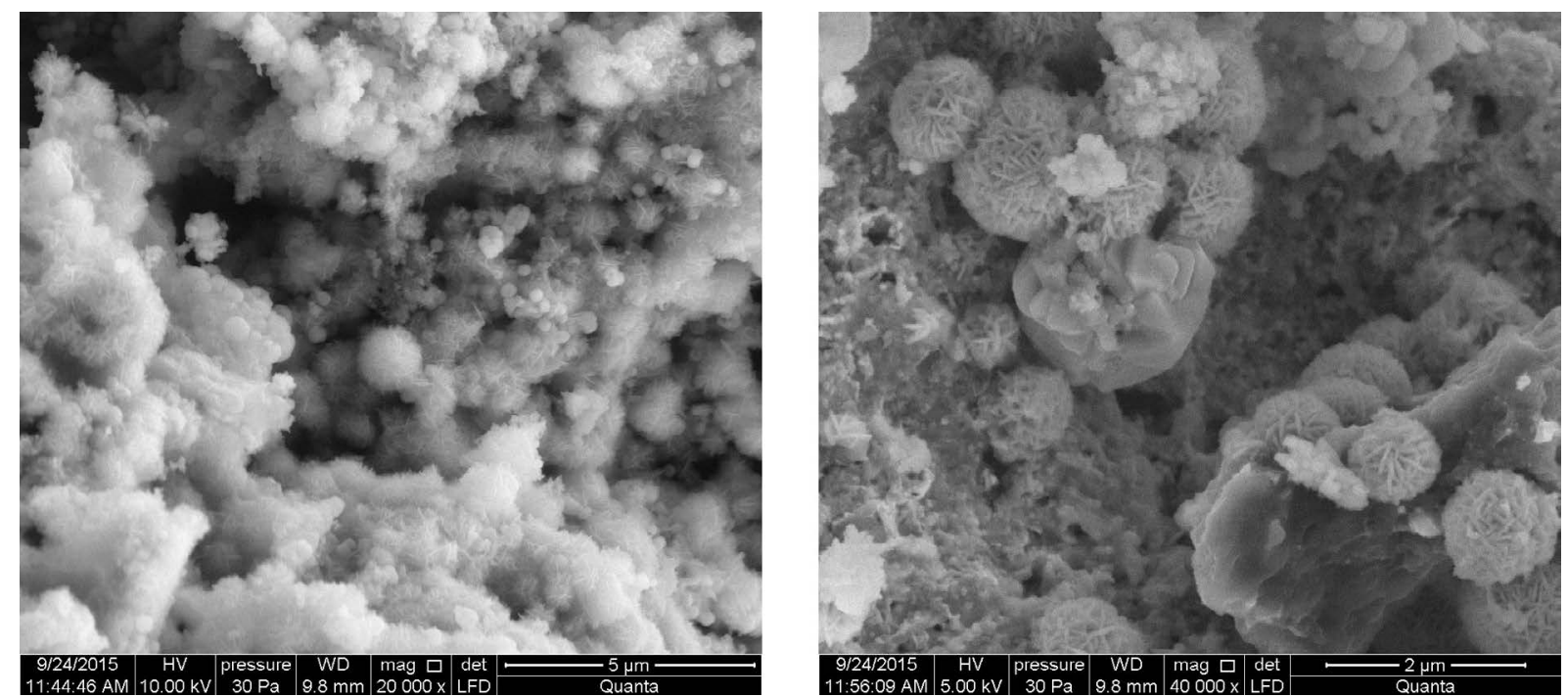

Figure 11. SEM of sample S8 


\section{Acknowledgements}

The project was funded by the National Science Centre allocated on the basis of the decision DEC-2011/03/D/ST8/04984, in Poland.

\section{REFERENCES}

1. Bandura, L., Panek, R., Rotko, M. and Franus, W. 2016. Synthetic zeolites from fly ash for an effective trapping of BXT in gas. Microporous and Mesoporous Materials, 223, 1-9.

2. Bayati, B., Babaluo, A.A. and Ahmadian, N.P. 2009. Synthesis and seeding time effect on the inter-crystalline structure of hydroxyl-sodalite zeolite membranes by single gas $\left(\mathrm{H}_{2}\right.$ and $\left.\mathrm{N}_{2}\right)$ Permeation. Iran Journal Chemistry Engineering, 28, 1-12.

3. Boycheva. S., Zgureva. D. and Shoumkova, A. 2015. Recycling of lignite coal fly ash by its conversion into zeolites. Coal Combustion and Gasification Products.7. 1-8.

4. Bukhari, S.S., Behin, J., Kazemian, H. and Rohani, S. 2014. A comparative study using direct hydrothermal and indirect fusion methods to produce zeolites from coal fly ash utilizing single-mode microwave energy. Journal of Material Science. 49. 8261-8271.

5. Carlos, A., Rios, R., Craig, D.W and Clive L.R. 2009. A comparative study of two methods for the synthesis of fly ash - based sodium and potassium type zeolites.Fuel.88.1403-1416.

6. Chen, C-H., Chiou, I-J. and Wang, K-S. 2006. Sintering effect on cement bonded sewage sludge ash. Cement and Concrete Composites. 28.26-32.

7. Commission of European Communities, Council Directive 86/278/EEC of 4 July 1986 on the protection of the environment, and in particular of the soil, when sewage sludge is used in agriculture.

8. Commission of European Communities, Council Directive 91/271/EEC of 21 March 1991 concerning urban wastewater treatment, amended by the 98/15/EC of 27 February 1998.

9. Commission of European Communities, Council Directive 99/31/EC of 26 April 1999 on the landfill of waste.

10. de Gennaro, R. , Cappelletti P., Cerri, G., de Gennaro, M., Dondi, M. and Langella, A. 2004. Zeolitic tuffs as raw material for lightweight aggregates. Applied Clay Science. 25. 71-78.

11. Donatello, S., Freeman-Pask A., Tyrer M. and Cheseman C.R. 2010. Effect of milling and acid washing on the pozzolanic activity of incinerator sewage sludge ash. Cement Concrete Composites. 2. 54-61.

12. Dyer, A. 1988. An introduction to zeolite molecular sieves. New York. Wiley.
13. Fotovat, F., Kazemian H. and Kazemein, M. 2009. Synthesis of $\mathrm{Na}-\mathrm{A}$ and faujasitic zeolites from high silicon fly ash. Mineral Research Bulletin. 44, 913-917.

14. Franus, W. and Wdowin, M. 2010. Removal of ammonium ions by selected natural and synthetic zeolites. Mineral Resources Management. 26, 133-148.

15. Fukui, K., Nishimoto, T., Takiguchi, M., and Yoshida, H. 2006. Effect of $\mathrm{NaOH}$ concentration on zeolite synthesis from fly ash with hydrothermal treatment method. KONA Power and Particle Journal. 24, 183-190.

16. Htun, M.M.H., Htay, M.M., and Lwin, M.Z. 2012. Preparation of Faujasite type Zeolite $\mathrm{X}$ from pure silica and alumina sources. Presented at The Second International Congress on Interdisciplinary Research and Development, Thailand, 31 May-1 June.

17. Juan, R. , Hernandez, S., Andres, J. M., and Ruiz, C. 2007. Synthesis of granular zeolitic materials with high cation exchange capacity from agglomerated coal fly ash. Fuel. 86. 1811-1821.

18. Kazemian, H., Naghdali, Z., Kashani, G., and Farhadi, F. 2010. Conversion of high silicon fly ash to Na-P1 zeolite: Alkaline fusion followed by hydrotermal crystalization. Advanced Powder Technology. 21, 279-283.

19. Latosińska, J., and Gawdzik, J. 2014. The impact of combustion technology of sewage sludge on mobility of heavy metals in sewage sludge ash. Ecological Chemistry and Engineering S.21. 465-475.

20. Lee, J.S., Eom, S.W., and Choi, H.Y. 2007. Synthesis of zeolite from sewage sludge incinerator fly ash by hydrothermal reaction in open system. Korean Journal of Environmental Health. 33, 317-324.

21. Lee, K.M., and Jo, Y.M. (2010). Synthesis of zeolite from waste fly ash for adsorption of $\mathrm{CO}_{2}$. Journal Material Cycles Waste Management. 12. 212-219.

22. Lee, M-G., Yi., G., Ahn, B., and Roddick, F. 2000. Conversion of coal fly ash into zeolite and heavy metal removal characteristics of the products. Korean Journal of Chemistry Engineering. 17. 325-331.

23. Liew, A.G., Idris, A., Samad, A.A., Noor, M.J.M. M. and Baki. A.M. 2004. Incorporation of sewage sludge in clay brick and its chracterization, Waste Management and Research. 22.226 - 233.

24. Littlewood, J., Shaw, S., Bots, P., Peacock, C., Trivedi, D. and Burke, I. 2015. Effect of solution composition on the recrystallization of kaolinite to feldspathoids in hyperalkaline conditions: limitations of pertechnetate incorporation by ion competition effects. Mineralogical Magazine. 79, 1379-1388. 
25. Molina A. and Poole C. 2004. A comparative study using two methods to produce zeolite from fly ash. Mineral Engineering, 17, 167-173.

26. Monzó J., Payá J., Borrachero M.V. and Girbés I. 2003. Reuse of sewage sludge ashes (SSA) in cement mixtures: the effect of SSA on the workability of cement mortars. Waste Management, 23, 373-381.

27. Mulgundmath, V.P., Tezel, F.H., Saatcioglu, T. and Golden, T.C. 2012. Adsorption and separation of $\mathrm{CO}_{2} / \mathrm{N}_{2}$ and $\mathrm{CO}_{2} / \mathrm{CH}_{4}$ by $13 \mathrm{X}$ Zeolite. Microporous and Mesoporous Materials, 90, 730-738.

28. Murayama, N., Yamamoto, H. and Shibata, J. 2002. Mechanism of zeolite synthesis from coal fly ash by alkali hydrothermal reaction. International Journal of Mineral Processing, 64, 1-17.

29. Osmanoğlu, A.E. 2006. Treatment of radioactive liquid waste by sorption on natural zeolite in Turkey. Journal of Hazardous Material, B137, 332-335.

30. Park, M.,Choi, Ch.L., Lim, W.T., Kim, M.Ch., Choi, J. and Heo, N.H. 2000. Molten-slat method for the synthesis of zeolitic materials: I. Zeolite formation in alkaline molten-slat system. Microporous and Mesoporous Materials, 37, 81-89.

31. Petterson, A., Zevenhoven, M., Steenari, B.M. and Åmand, L.E. 2008. Application of chemical fractionation methods for characterization of biofuel, waste derived fuels and CFB co-combustion fly ashes. Fuel, 87, 3183-3193.

32. Pichór, W., Mozgawa, W., Król, M. and Adamczyk, A. 2014. Synthesis of the zeolites on the lightweight aluminosilicate fillers. Materials Research Bulletin, 49, 210-215.

33. Polat, E., Karaca, M., Demir, H. and Onus, N. 2004. Use of natural zeolite (clinoptiolite) in agriculture. Journal of Fruit and Ornamental Plant Research, 12, 183-189.

34. Qiu, W., and Zheng Y. 2009. Removal of lead, copper, nickel, cobalt, and zinc from water by a cancrinite-type zeolite synthesized from fly ash. Chemical Engineering Journal, 145, 483-488.

35. Querol X., Moreno N., Umana J.C., Alastuey A., Harnandez E., Lopez-Soler A. and Plana F. 2002. Synthesis of zeolites form coal fly ash: an overview. International Journal of Coal Geology, 50, 413-423.

36. Querol, X., Alastuey, A., Fernandezturiel, J.L. and Lopezsoler, A. 1995. Synthesis of zeolites by alkaline activation of ferro-aluminus fly-ash. Fuel, 74, 1226-1231.

37. Rayalu, S., Meshram, S.U. and Hasan, M.Z. 2000. Highly crystalline faujasitic zeolites from flyash. Journal of Hazardous Materials, B77, 123-131.

38. Ruiz, R., Banco C., Pesquera, F., Gonzalez, F., Benito, I. and Lopez, J.L. 1997. Zeolitization of a bentonite and its application to removal of ammonium ion form waste water. Applied Clay Science, 12, 73-83.
39. Shigemoto, N., Hayashi, H. and Miyara. K. 1993. Selective formation of $\mathrm{Na}-\mathrm{X}$ zeolite from coal fly ash by fusion with sodium hydroxide prior to hydrothermal reaction. Journal of Material Science, $28,4781-4786$.

40. Stamires, D.N. 1973. Properties of the zeolite, faujasite substitutional series: a review with new date. Clays and Clay Minerals, 21, 379-389.

41. Takahashi, M., Kato, S. and Iwasaki, S. 2001. Technology for recovering phosphorus salt and zeolite from incinerated ash of sewage treatment sludge. Journal of Advanced Science, 13, 163-166.

42. Tanaka, H., Furusawa, S. and Hino, R. 2002. Synthesis, Characterization and Formation Process of Na-X Zeolites from Coal Fly Ash. Journal of Material Synthetic Processing, 10, 143-148.

43. Thuadaij. P. and Nuntiya, A. 2012. Preparation and characterizatoin of faujasite using fly ash and amorphuus silica from rice husk ash. Procedia Engineering, 32. 1026-1032.

44. Wainwright P.J. and Cresswell D.J.F. 2001. Synthetic aggregates from combustion ashes using an innovative rotary kiln. Waste Management, 21, 241-246.

45. Wajima T. and Ikegami Y. 2009. Synthesis of crystalline zeolite-13X from waste porcelain using alkali fusion. Ceramic International, 35, 2983-2986.

46. Wajima, T. and Munakata, K. 2014. Preparation of zeolitic material with simultaneous removal of $\mathrm{NH}_{4}^{+}$and $\mathrm{PO}_{4}^{-}$from paper sludge ash via acid leaching. Journal of Material Cycles Waste Management, 16, 367-372.

47. Wałek, T.T., Saito, F. and Zhang, Q. 2008. The effect of low solid/liquid ratio on hydrothermal synthesis of zeolites from fly ash. Fuel, 87, 3194-3199.

48. Wang K.-S., Chiou I-J., Chen Ch-H., and Wang D. 2005. Lightweight properties and pore structure of foamed materialmade from sewage sludge ash. Construction and Building Materials, 19, 627-633.

49. Wdowin, M., Franus, M., Panek, R., Badura, L., and Franus, W. 2014. The conversion technology of fly ash into zeolites. Clean Technology Environmental Policy, 16, 1217-1223.

50. Zhang, M., Zhang, H., Xu, D., Han, L., Niu, D., Zhang, L., Wu, W. , and Tian, B. 2011. Ammonium removal from aqueous solution by zeolites synthesized from low-calcium and high-calcium fly ashes. Desalination, 277, 46-53.

51. Zhu, J., Meng, X., and Xiao, F. 2013. Mesoporous zeolites as efficient catalysts for oil refining and natural gas conversion. Frontier of Chemical Sciences and Engineering, 7, 233-238.

52. Żygadło, M., Seweryn, A., Woźniak, M., and Latosińska, J. 2011. Recycling ash from recovery plant energy as an example of realization of the idea of sustainable development. Problems of Sustainable Development, 6, 207-214. 